\title{
Inside the Nation of Islam
}

Vibert L. White, Jr.

Gainesville, FL: University Press of Florida, 2001. 256 pages.

The author, who embraced the teachings of Louis Farrakhan's revamped Nation of Islam (NOI) in the late 1970s to find solutions to America's race problems, left disillusioned in the mid-1990s. What he witnessed as he passed through the organization's rank and file compelled him to compile his experiences to give others a clearer understanding of the Nation's origins as well as its role concerning the issues facing African-Americans.

Inside the Nation of Islam is divided into 11 chapters and contains a foreword by Mike Wallace an epilogue by the author, extensive notes, a bibliography, and an index. Also included are several photographs that illustrate White's extensive involvement in the NOI.

With a brief overview of African-American history prior to the NOI's creation, chapters 1 and 2 touch on the Harlem Renaissance, the origin of the Jim Crow laws, and the mass exodus of African-Americans from the South to the North. With the fall of similar resistance movements, the NOI stepped in to address the bitter disillusionment that many of them experienced upon their arrival in the North. 
Elijah Poole, later known as Elijah Muhammad, was among the millions who sought reprieve from the South's brutality. In Detroit, Poole accepted the teachings of Wallace Fard Muhammad, the founder of the Lost Found Nation of Islam in the Wilderness of North America, who called himself "Allah." With Fard's disappearance in 1934, Muhammad became the leader of an organization that became infamous for its black supremacist stance and its blatant hatred of whites.

With the introduction of the NOI's most famous members, Malcom $\mathrm{X}$ and Louis Farrakhan in chapter 3, simply titled "Malcolm: Mentor, Rival, Enemy," White proceeds to the heart of the book: his role in the NOI. In chapter 4, aptly titled "Personal Testimony," White narrates his progress from foot soldier to minister in the NOI's upper echelons by recalling how he was initially forced to sell newspapers and bean pies, and how he was subject to the NOI's call at all times.

White outlines his argument in this chapter, and in the following two, that the NOI is a racist, exploitative institution that forces and intimidates its members into submission. The poorest were expected to donate large portions of their meager incomes while the causes for which the money was raised never came to fruition. Farrakhan and his family, however, continued to increase their wealth. Citing such failed business ventures as, among many others, the whiting fish business, the cosmetics line, and the newspaper and bean pie industry, White details how ineptitude, mismanagement, and greed ultimately bankrupted the NOI. Possible links to criminal activities cast further doubt on its integrity.

Farrakhan's anti-Semitism, racism, and anti-government views speak for themselves in chapter 7, "Farrakhan Speaks: Conventions, Rallies, and Savior's Days," and became more apparent as he was forced to deal with the repercussions of a hostile speech given by his top aide in chapter 8, "Cain and Abel: Division in the Brotherhood."

Further evidence of corruption is elucidated in chapter 9, "The Story behind the Million Man March," in which White grudgingly praises Farrakhan's charismatic ability to convince the foremost African-American leaders to participate in hosting the largest march on Washington, DC, ever witnessed in American history. The march's success, says White, was marred by Farrakhan's misuse of the millions of dollars donated, which irreparably damaged his reputation, as witnessed by the failure of similar events over the following years.

When it became apparent that another source of revenue was needed, White states that Farrakhan turned to the international stage as he and the 
NOI befriended such nations as Libya, Iraq, and Iran. Winning the alliance of Libya's Qadhafi brought Farrakhan a \$5 million loan, as detailed in chapter 10, "Farrakhan's World Tours." However, White alleges that this money was not used to better the African-American community, as Farrakhan had insisted, but rather made Farrakhan wealthier. Even more interesting, Farrakhan appeared to reconcile the NOI's belief system with that of orthodox Islam to appease Qadhafi and other Muslim leaders. Yet another ploy, says White, who points out that when pressured by NOI hardliners, he quickly reaffirmed his belief in Elijah Muhammad's creed of black supremacy.

The final chapter "A New Nation: The Millennium" and the Epilogue solidify White's argument with an analysis of the NOI's role in the continuing dialogue on America's race problem. According to him, the NOI ultimately failed to achieve its lofty ideals and aims because Farrakhan strayed from Elijah Muhammad's teachings of black self-sufficiency. As long as the NOI continues to pander to Farrakhan's desire for power, wealth, and influence, concludes White, it will continue to prey upon and exploit those whom it most seeks to help.

White makes a compelling argument that the NOI's potential for proactively addressing the concerns of the African-American community is, unfortunately, lost in the exploitative tactics it uses to enhance its wealth and image. While White's accounts of intimidation and manipulation are convincing, once the argument moves to Farrakhan, it amounts to nothing more than a personal attack supported by evidence that is speculative at best.

Among several inaccuracies that detract from the solidity of White's thesis is his explanation that Islam was brought to Africa from Arabia after the death of the "Prophet Muhammad of the tribe of Shabazz."

Despite its use of both Islamic and Christian doctrine and practices, the NOI, as White clarifies, is not a religious organization but a nationalistic affiliation. Lamenting its failure to address the spiritual needs of its membership, White observes that many who leave the group return to lives of crime, prostitution, and drugs. White concludes on a somber note "We were concerned not just because they left Farrakhan and Elijah Muhammad's teaching, but because they left the totality of Islam." 